\title{
Modelling Urban Wisdom Growth of Sustainable Development
}

\author{
Zaiqiang $\mathrm{Ku}^{*}$ and Pei Guo \\ College of Mathematics and Physics, Huanggang Normal University, Huanggang 438000, Hubei, China \\ ${ }^{*}$ Corresponding author
}

\begin{abstract}
A model for urban wisdom growth of sustainable development is proposed in this paper. Based on the entropy weight method and the gray relational analysis, we calculate the weight of each index and the correlation coefficient between the indicators, and get the urban intelligent growth indexes andobtain the annual growth rate of the composite indexes.The innovation of this paper is that the entropy weight method and the gray relational analysis method are applied to evaluate the urban intelligence growth index for the first time and calculate the growth rate of the annual comprehensive indexes. The success degree of urban intelligent growth is divided by the annual growth rate divided by the current growth rate.
\end{abstract}

Keywords-smart city; annual growth rate; urban sustainable; urban sustainable development

\section{INTRODUCTION}

The discussion around the cities and their development has never stopped. Moving from the "industrial city" to the "city of services" and, finally, to contemporary urban conurbations, the city has indeed experimented issues of a different nature related to its growth. In these years of "urban re-concentration" social problems have emerged, related to the provision of essential services such as housing and education at an affordable cost, a social environment without crime, safe and inclusive, but also innovative services, in addition to the problems of congestion, pollution and physical degradation. In response to these challenges, after the models of urban sustainability represented by the "green city" and the "creative city", taking shape new paradigm for the modern city, the "smart growth city". ${ }^{[1]}$

Many communities are implementing smart growth initiatives in an effort to consider long range, sustainable planning goals. Smart growth covers a range of development and conservation strategies that help protect our health and natural environment and make our communities more attractive, economically stronger, and more socially diverse. ${ }^{[2]}$ Smart growth focuses on building cities that embrace the E's of sustainability--Economically prosperous, socially Equitable, and Environmentally Sustainable. This task is more important than ever because the world is rapidly urbanizing. It is projected that by 2050, 66 percent of the world's population will be urban--this will result in a projected 2.5 billion people being added to the urban population ${ }^{[3]}$

Smart growth of a city has 10 principles ${ }^{[4]}$, which must be tailored to a community's unique needs to be effective. In general, any measure of success must incorporate the demographics, growth needs, and geographical conditions of a city as well as the goal to adhere to the three E's. Therefore, this paper investigates how to use smart growth theory to measure the smart growth degree of two cities-Suzhou and Sao Luis.

\section{EVAluAtion SyStem OF SMART GROWTH City}

According to the three-E principles of city sustainable development that are economic prosperity, social equity and environmental sustainable development to determine the index of city smart growth composite index.

\section{A. The Establishment of City Smart Growth Evaluation}

The science evaluation system is the basis of economic prosperity, social justice and the sustainable development of environment.

According to these principles, we will take the success of the city smart growth degree as the primary; Intelligent economy, intelligent community, intelligent environment as a secondary indicator; GDP, the total amount of import and export, total export, the city's total population, the number of primary endowment insurance, every one thousand people have health organization personnel, professional and technical personnel and city built-up area, the bus operating line the total length, taxi operating vehicles, the area built up green area, the intensity of sulfur dioxide emissions per unit of GDP, industrial waste water processing as level third indicators. (See Table 1)

\section{TABLE I. INDICTOR SYSTEM OF SMART GROWTH OF THE CITY}

\begin{tabular}{|c|c|c|}
\hline \multirow{13}{*}{$\begin{array}{l}\text { City smart } \\
\text { growth } \\
\text { evaluation }\end{array}$} & \multirow{3}{*}{$\begin{array}{l}\text { Intelligent } \\
\text { economy }\end{array}$} & GDP \\
\hline & & The total amount of import and export \\
\hline & & total export \\
\hline & \multirow{7}{*}{$\begin{array}{l}\text { Intelligent } \\
\text { Community }\end{array}$} & The city's population \\
\hline & & The basic old-age insurance number \\
\hline & & $\begin{array}{l}\text { Every one thousand people with health } \\
\text { agency data }\end{array}$ \\
\hline & & Professional and technical personnel \\
\hline & & city built-up area \\
\hline & & The bus operating line the total length \\
\hline & & Taxi operation vehicle \\
\hline & \multirow{3}{*}{$\begin{array}{l}\text { Intelligent } \\
\text { Environment }\end{array}$} & Built up area green area \\
\hline & & $\begin{array}{c}\text { The intensity of sulfur dioxide emissions per } \\
\text { unit of GDP }\end{array}$ \\
\hline & & Industrial waste water processing \\
\hline
\end{tabular}




\section{B. The Reason of Select Indicators}

- A city economic levels, is mainly reflected in the GDP, the total import and export, export volume.

- A city intelligent level of socialization mainly reflected in the city's total population, the number of primary endowment insurance, the basic old-age insurance number, Professional and technical personnel, city built-up area, bus line, The bus operating line the total length.

- A city economic environment optimization degree, mainly reflected in the Built up area of green area, The intensity of sulfur dioxide emissions per unit of GDP, Industrial waste water processing.

\section{The CuRrent DeVElopment Plan Evaluation}

\section{A. The Establishment of Comprehensive City Smart Growth} Index

Empowerment of entropy method[5] is a method of weight in the evaluation.Grey correlation analysis method is one way to measure the correlation degree between the factors. Grey correlation theory is put forward the concept of grey correlation analysis of each factor, through a certain method, to seek the numerical relationship between each factor in the system. We use the entropy weight method and gray correlation analysis method combined with the method to determine the comprehensive index.

\section{1) The Entropy Weight Method to Establish Weights}

In the methodology of information, entropy is a measure of uncertainty thing. When the information quantity is greater, the uncertainty value and entropy is smaller, while the information quantity is smaller, and the uncertainty value and entropy is greater. According to its characteristics, we can calculate the entropy and tell the random and disorder of a certain event.Entropy value can also be used to determine an index of discrete degree.

This paper use the software to standardize city from 2010 to 2015 data processing, then use of entropy method to calculate three-level indicator GDP, the total import and export, export volume, the city's total population, the number of primary endowment insurance, each have health organization \&personnel, professional and technical personnel one thousand people, operating area is, bus lines, the total length of the taxi operating vehicles, built up area green area, the strength of sulfur dioxide emissions per unit of GDP, the rate of industrial waste water weight, specific steps are as follows:

- according to the formula

$$
p_{i j}=\frac{x_{i j}}{\sum_{i=1}^{m} X_{i j}}
$$

- calculation index $x_{i j}$ weight $p_{i j}$ under index j; according to the formula $e_{j}=-k \sum_{i=1}^{m} p_{i j} \ln p_{i j}$ of index $j$ entropy, $k=\frac{1}{\ln m}$

- according to the formula $d_{j}=1-e_{j}$,to calculate index $j$ factor the difference of the $d_{j}$

- finally according to the formula

$$
w_{j}=\frac{d_{j}}{\sum_{j=1}^{n} d_{j}} .
$$

We can calculate the weight of each index $j$;

\section{2) Grey Correlation Analysis}

Based on the correlation coefficient of each index, grey correlation method of the calculation process is as follows

- First of all, using SPSS13.0 software to dimensionless selected data Analysis and processing, the result can get the corresponding dimensionless matrix.

- Solve the absolute difference sequence, the biggest difference between poor $\Delta(\max )$ and the minimum difference two-stage least $\Delta(\min )$

Absolute difference sequence calculation formula is

$$
\Delta_{i j}=\left|x_{i j}-x_{0 j}\right|
$$

The biggest and smallest difference between the calculationscan be written as

$$
\Delta \max =\max \cdot \max \Delta_{i j}, \Delta \min =\min \cdot \min \Delta_{i j}
$$

- Calculating correlation coefficient: according to the formula:

$$
\xi_{i j}=\frac{\Delta_{\max }+k \Delta_{\max }}{k \Delta_{\max }},
$$

where $\mathrm{k}$ is coefficient distinguish among them, value is 0.5 .

- Finally, calculate comprehensive index of city smart growth. Calculation formula is:

$$
f_{i}=\sum_{j=1}^{n} w_{j} \xi_{i j}
$$

The urban smart growth index from 2010 to 2015 
TABLE II. SUZHOU SMART GROWTH INDEX FROM $2010 T O 2015$ GROWTH

\begin{tabular}{ccccc}
\hline year & $\begin{array}{c}\text { Intelligent } \\
\text { economic } \\
\text { index }\end{array}$ & $\begin{array}{c}\text { Intelligent } \\
\text { social index }\end{array}$ & $\begin{array}{c}\text { Intelligent } \\
\text { environment } \\
\text { index }\end{array}$ & $\begin{array}{c}\text { Smart growth } \\
\text { index }\end{array}$ \\
\hline 2010 & 0.1077 & 0.0484 & 0.0492 & 0.2053 \\
2011 & 0.1613 & 0.0569 & 0.0658 & 0.284 \\
2012 & 0.2188 & 0.08 & 0.1292 & 0.428 \\
2013 & 0.2299 & 0.0873 & 0.0906 & 0.4078 \\
2014 & 0.317 & 0.1412 & 0.0577 & 0.5159 \\
2015 & 0.3232 & 0.1451 & 0.0431 & 0.5114 \\
\hline
\end{tabular}

TABLE III. SAINT LOUIS SMART GROWTH INDEX FROM $2010 T 02015$ GROWTH

\begin{tabular}{lclll}
\hline year & $\begin{array}{c}\text { Intelligent } \\
\text { economic } \\
\text { index }\end{array}$ & $\begin{array}{c}\text { Intelligent } \\
\text { social index }\end{array}$ & $\begin{array}{c}\text { Intelligent } \\
\text { environment index }\end{array}$ & $\begin{array}{c}\text { Smart growth } \\
\text { index }\end{array}$ \\
\hline 2010 & 0.4263 & 0.0704 & 0.0704 & 0.5671 \\
2011 & 0.1758 & 0.0802 & 0.0802 & 0.3362 \\
2012 & 0.1584 & 0.0929 & 0.0929 & 0.3442 \\
2013 & 0.1426 & 0.1122 & 0.1122 & 0.367 \\
2014 & 0.1531 & 0.1447 & 0.1447 & 0.4425 \\
2015 & 0.1421 & 0.2113 & 0.2113 & 0.5647 \\
\hline
\end{tabular}

It can be seen from the tables, the smart growth of Suzhou composite index generally on the rise, and Saint Louis smart growth index have been substantially rise after falling.

\section{B. The Composite Index, the Rate of Change}

City are calculated respectively from 2011 to 2015, the intelligence of year-on-year growth in 2015 composite index of growth, judging by city smart growth each year growth rate of the composite index of growth, When the growth rate is greater than 0 , the Suzhou current plan is a success, on the other hand is failure. Again to do the annual growth rate of average, through the average growth rate to judge success degree.

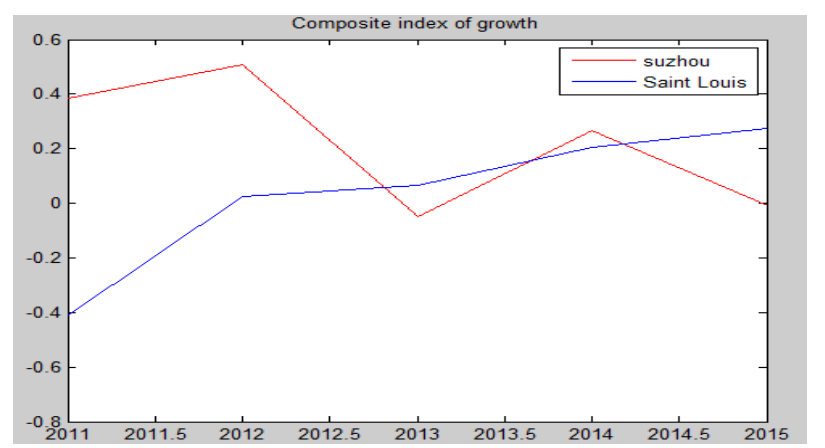

FIGURE I. COMPOSITE INDEX OF GROWTH

\section{CITY Plans FOR FUtURE GROWTH}

\section{A. Growth Plan in Suzhou}

\section{1) Location}

Rapid consumption of land resources has broken through the planning and control the size of the index of land. Population scale and facilities are difficult to support. It is worth noting that area traffic location advantage is being weakened in Suzhou, reach the internal plates scattered independent development, rapid transport links support is insufficient, the urban centricity is not strong. Urban traffic organization still keep ancient city as the core, close to the limit capacity, and contradict with ancient city protection. Aiming at this problem, we should control of urban area , the maximum use compact, build "bus + go slow" mode of transport, in and out of the old city dominated by rail transit, limit car, lengthen the bus operation of the road long and increase rental operation of the vehicle.

\section{2) Economic Opportunities}

In recent years, manufacturing industry is the core of the Suzhou industry and is the most important brand resources. However, Suzhou's manufacturing processing is given priority to, low added value, land input is high, and output efficiency is not high. So, we deal with Suzhou industry to choose and give up. we build "transverse promotions, vertical axis agglomeration; science and technology production, the east side to the west cultural innovation; south wen gen service, advanced manufacturing technology of the north" of the industry layout structure, improve the GDP, the total import and export and the total exports.

\section{3) Expected Rate of Growth}

By counting trends of intelligent community, intelligent economy, intelligent environment from 2010 to 2015, we get the index trend shown asFigure.2.

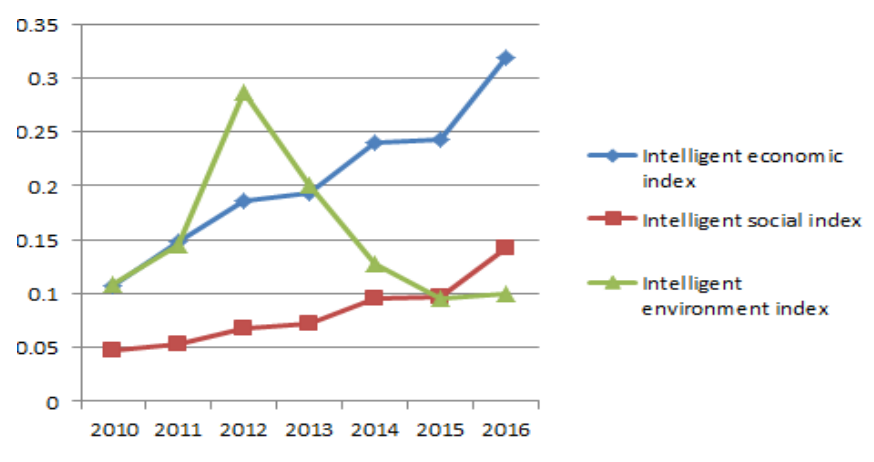

FIGURE II. SUZHOU INDEX TREND DIAGRAM

\section{4) Growth Plan in Future}

Here, we propose a bold vision: in 2050, the GDP growth of $21 \%$, the total import and export growth of $13 \%$, the total export growth of $8 \%, 10 \%$ growth in total population in the city, the basic old-age insurance coverage increased $12 \%$ per one thousand people, with health agency data growth of $7 \% 15 \%$ growth, professional and technical personnel and operating area is increased by $6 \%$, and the bus line the total length increased by $7 \% 3 \%$ growth, taxi operation vehicle, built up area green area increased by $8 \%$, sulfur dioxide emissions intensity per unit of GDP by $12 \%$, $20 \%$ growth rate of industrial waste water.

\section{5) Growth Plan Success Degree Evaluation}

We will calculate all the indexes in 2050 based on the original data in 2015 in accordance with the expectations hypothesis respectively, the total GDP' import and export, the 
export volume, the city's total population, the number of primary endowment insurance, each have health organization \&personnel, professional and technical personnel one thousand people, operating area is, bus lines, the total length of the taxi operating vehicles, built up area green area), the strength of sulfur dioxide emissions per unit of GDP, the rate of industrial waste water prediction, then according to the comprehensive index of the predicted values to assess growth plan, the comprehensive index and composite index in 2015, in order to assess the degree of success of the plan.

TABLE IV. IN 2015 AND 2050 COMPOSITE INDEX IN SUZHOU

\begin{tabular}{ccccc}
\hline year & $\begin{array}{c}\text { Intelligen } \\
\mathrm{t} \\
\text { economic } \\
\text { index }\end{array}$ & $\begin{array}{c}\text { Intelligent } \\
\text { social } \\
\text { index }\end{array}$ & $\begin{array}{c}\text { Intelligent } \\
\text { environment } \\
\text { index }\end{array}$ & $\begin{array}{c}\text { Composite index o } \\
\text { f growth }\end{array}$ \\
\hline 2015 & 0.1905 & 0.1139 & 0.1288 & 0.4332 \\
2050 & 0.3194 & 0.2026 & 0.3863 & 0.9083 \\
\hline
\end{tabular}

Can be seen from the table, after the growth and decline of the plan of each index, the smart growth of Suzhou composite index increased significantly, and in 2015 grew by 109.67\%, on the basis of the judgment of our plan was a great success.

\section{B. Saint Louis Growth Plans}

\section{1) Location}

Saint Louis is the only independent city, Missouri, is the state's second largest city. When the local repair the buildings, not only to maintain its original true and integrity, still added some modern service function. So we have to increase the number of primary endowment insurance, every one thousand people have health organization \&personnel, professional and technical personnel, lengthen the bus operation of the road long and increased rental operation of the vehicle.

\section{2) Economic Opportunities}

Saint Louis had the important industrial city in the United States and central land and sea transport hub, the Saint Louis's most important industry is the service industry. So we have to increase total GDP, import and export and export volume, in order to improve the intelligent economic comprehensive index.

\section{3) The Expected Rate of Growth}

By counting trends of intelligent community, intelligent economy, intelligent environment from 2010 to 2015, we get the index trend shown asFigure.3.

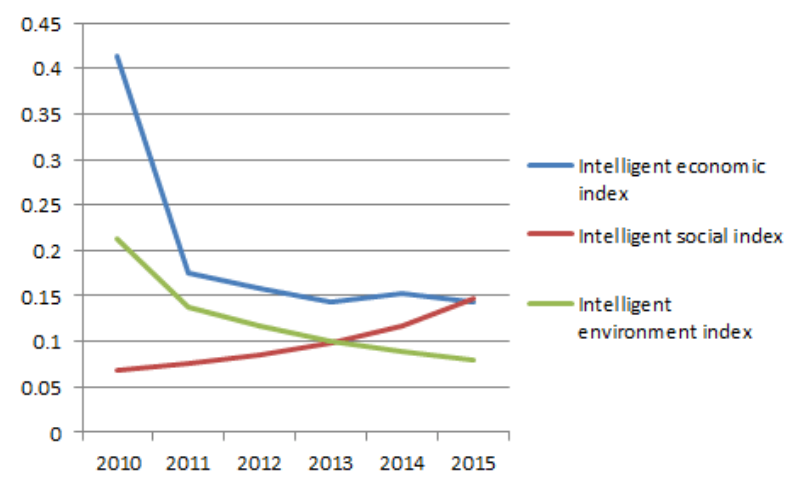

FIGURE III. SUZHOU INDEX TREND DIAGRAM

\section{4) Growth Plan in the Future}

Improve the total GDP, import and export and export volume, reduce the number of population, increasing the size of the basic endowment insurance, every one thousand people with health authorities of beds, professional and technical personnel and operating area is, bus lines, taxi operating vehicles, the total length of proper green area, processing, industrial waste water, reduce sulfur dioxide emissions per unit of GDP.

\section{5) Growth Plan Success Degree Evaluation}

With Suzhou growth plan success degree evaluation system, through calculating the forecast of each index, composite index to assess growth plan, the comprehensive index and composite index in 2015, according to projections to assess growth plan of composite index, calculate its growth rate, growth rate and the ratio of average growth rate of its success

TABLE V. IN 2010 AND 2050 COMPOSITE INDEX IN SAINT LOUIS

\begin{tabular}{ccccc}
\hline year & $\begin{array}{c}\text { Intelligent } \\
\text { economic } \\
\text { index }\end{array}$ & $\begin{array}{c}\text { Intelligent } \\
\text { social } \\
\text { index }\end{array}$ & $\begin{array}{c}\text { Intelligent } \\
\text { environment } \\
\text { index }\end{array}$ & $\begin{array}{c}\text { Composite index of } \\
\text { growth }\end{array}$ \\
\hline 2015 & 0.2365 & 0.1492 & 0.1324 & 0.5181 \\
2050 & 0.2397 & 0.1948 & 0.381 & 0.8155 \\
\hline
\end{tabular}

It can be seen from the Table 5, after planning each index of the growth and decline. The smart growth of Suzhou composite index increased significantly, and in 2015 grew by $57.4 \%$, on the basis of the success is $57.4 \%$, so our plan is relatively successful.

\section{SENSITIVITY ANALysis}

We will increase $10 \%$ each index respectively and other indicators remain the same. We use of entropy method and the grey correlation analysis method to determine the comprehensive index and analyze the resulting composite index. According to the index changes impact on the composite role sort

It can be found the index changes of Suzhou for the city's green area $>$ proper population bus operating line the total length $>$ rate of industrial waste water taxi operating cars $>$ basic endowment insurance number $>$ original data export total $=$ the total export in one thousand people with health organization \&personnel $=$ of professional and technical personnel area is $>$ gross regional product.

According to the weight of each index, the weight of professional and technical personnel is 0.8539 in Suzhou, and the total weight of Saint Louis's export is 0.8795 . Therefore, when each city's population Growth of 50\% in 2050. Suzhou can increase the professional and technical personnel, Saint Louis through the total export volume to support this level of growth.

\section{REFERENCES}

[1] Greco I, Bencardino M. The Paradigm of the Modern City: SMART and SENSE able Cities, for Smart, Inclusive and Sustainable Growth[M]// Computational Science and Its Applications - ICCSA 2014. Springer International Publishing, 2014:579-597.

[2] EPA, “This is Smart Growth.” 2016. 
https://www.epa.gov/smartgrowth/smart-growth-publication

[3] World Urbanization Prospects. United Nations. 2014.

https://esa.un.org/unpd/wup/Publications/Files/WUP2014-Highlights.pdf.

[4] EPA, "Smart Growth: A Guide to Developing and Implementing Greenhouse Gas Reductions Programs.”, 2011.

http://www.sustainablecitiesinstitute.org/Documents/SCI/Report_Guide/ Guide_EPA_SmartGrowthGHGReduction_2011.pdf

[5] Reguo, F.: Entropy Weighting Ideal Point Method and its applications in investmentdecision making. J. Wuhan Univ. of Hydr. \& Elec. Eng. 6 , 105-107 (1998)

[6] Shannon C E. A Mathematical Theory of Communication. Bell System Technical Joural,1984,27:623 656

[7] Thomas R W.InformationStatics in Geography. Norwich: W..H.Hutchins\&Sons, 19 